\title{
Factors That Influence English Teachers' Acceptance and Use of E-Learning Technologies
}

\author{
Yousif H. Al-Anezi ${ }^{1}$ \& Salem M. Alajmi ${ }^{2}$ \\ ${ }^{1}$ College of Basic Education, Public Authority for Applied Education and Training, Kuwait \\ ${ }^{2}$ Language Center, Public Authority for Applied Education and Training, Kuwait \\ Correspondence: Yousif H. Al-Anezi, College of Basic Education, Public Authority for Applied Education and \\ Training, Kuwait.
}

Received: April 7, 2021

doi:10.5539/ies.v14n9p15
Accepted: June 2, 2021

Online Published: August 22, 2021

URL: https://doi.org/10.5539/ies.v14n9p15

\begin{abstract}
The world has witnessed a major pandemic that has threatened the status of education across the globe. Such a crisis highlights the importance of education technology, which has not been an influential part of Kuwait's education until the onset of COVID-19. Delays and interruptions of the academic year disrupted the lives of many students around the world, including Kuwait. Since e-learning technologies are not traditionally used in Kuwaiti higher education, this study aims to investigate the acceptance of technology and whether that has changed with the pandemic. It seeks to find useful strategies that could assist teachers in effectively using electronic distance-learning digital resources. The Unified Theory of Acceptance and Use of Technology (UTAUT) has been developed to investigate the degrees of usage and acceptance of technology. This paper adopts an improved model that also includes the educational experience of teachers, in an attempt to understand the context of Kuwaiti higher education. Therefore, this quantitative study examines the use and acceptance of educational technologies of English language instructors in higher education.

The study uses an online survey among 33 English language instructors at the Public Authority for Applied Education and Training (PAAET) to also account for the perceptions and experiences of the teachers. The results revealed an overall high acceptance level of educational technology, with varying degrees of implementation.
\end{abstract}

Keywords: educational technology, e-learning, UTAUT, TAM, English language

\section{Introduction}

\subsection{The Impact of COVID-19 on Education in Kuwait}

COVID-19 has affected many sectors around the world, including health, education, society, economy, politics, and humanitarianism. The United Nations Educational, Scientific and Cultural Organization (UNESCO) showed that 1,344,914,000 students had their studies suspended, in 138 countries around the world (UNESCO, 2020). Kuwait is no exception in this respect, as the authorities enforced full lockdown and suspended schools and higher education beginning in mid-March 2020 (Reuters, 2020). However, as time progressed, Kuwait's Ministry of Education took the decision, in August 2020, to shift into electronic distance learning (KUNA, 2020).

As COVID-19 has brought learning in Kuwait to a halt, PAAET has intensified its process of embracing e-learning technology as it looked for feasible ways for students to resume studies during the pandemic. As part of this process, PAEET has provided access to Microsoft Teams and Moodle programs, on which instructors can upload syllabi and course content for their students, and on which classes can take place online.

\subsection{Importance of the Study}

Since the independence of the State of Kuwait in 1961, its education has largely been carried out on a face-to-face basis. In recent years, online education has started to emerge as a largely complementary tool, but it has only been used scarcely. Although there have been a few research studies carried out on the use of ICT in Kuwaiti education (Ashkanani, 2017; Al-Daihani, 2016; Alkandari, 2015; Rouibah \& Abbas, 2006), no studies have yet been dedicated to English language instructors from the Language Center at PAAET in Kuwait. Thus, this study aims to explore English teachers' acceptance and use of electronic distance and e-learning technologies. This is of interest not only because of the lack of research on this particular group, but also because English language courses mainly 
adopt textbooks developed by international organizations that provide access to e-learning tools. Many English language courses at PAAET use textbooks that provide companion digital packages for teaching and practice purposes, in addition to a considerable amount of free-access online material. This places English language courses at a better level than other courses in terms of course material and practice. Research has also shown that technology improves the language-learning process, with numerous programs and online services that make learning more accessible and enjoyable, such as learning vocabulary (Horst, Cobb, \& Nicolae, 2005). Furthermore, information technology increases collaboration and interaction among students, which are beneficial for the language-learning process (Kukulska-Hulme \& Viberg, 2018).

However, acceptance and utilization of new technologies by users is considered to be a primary indication of the success of the implementation and development of any educational technology approach. The attitudes of the user towards adopting new technologies are an essential indication of the success or failure of any information technology project (Succi and Walter, 1999; Pinto and Mantel, 1990). Venkatesh, Morris, G. Davis, and F. Davis (2003) see users' acceptance of technology as being the user's initial decision to interact with the technology.

\subsection{Literature Review}

Teachers' usage of technology is affected by numerous factors, and it is important to understand whether there is a relationship between their usage and their attitudes. Research (e.g. Nuttall, Edwards, Mantilla, Grieshaber, \& Wood, 2015; Sime \& Priestley, 2005) has shown disparity between teachers' attitudes and actual use of ICT. While the majority of teachers express favourable attitudes, their actual implementation of ICT is relatively limited. Shroff et al. (2011) state that manipulating these two factors helps system developers take better control over users' attitudes towards the technology. This in turn allows the system developers to predict the behavioural intention of the user and their actual application of the system. In addition, users' perceptions of technology can be a major factor in predicting their attitudes (Liu, 2010). Overall, research has repeatedly shown that attitudes towards using a new system could play a major role in influencing future behaviour, or at least give insight into the users' actual intentions, which could eventually lead to certain behaviours (Afshari et al., 2013; Elias et al., 2012).

There are also other factors that can influence the usage of ICT. For instance, the subject matter could affect users' attitudes, as Jimoyiannis and Komis (2007) state that, while foreign language, technology, and science teachers have apparent positive attitudes regarding ICT, other fields, such as social sciences teachers, conveyed negative attitudes. Additionally, the study found that male teachers show more positive attitudes to ICT than female teachers (Jimoyiannis \& Komis, 2007). Kalogiannakis (2010) reported similar findings, noting that age also could affect teachers' attitudes towards ICT, as younger teachers appear to be more in favor of adopting ICT in education than older teachers (Blackwell et al., 2014; Camilleri \& Camilleri, 2017; Kalogiannakis, 2010). On the other hand, Jimoyiannis and Komis (2007) suggested that older teachers with long teaching experiences show more positive attitudes towards e-learning technologies in education than less experienced teachers.

The likelihood that an educational institution will adopt ICT also depends on that institution's infrastructure and financial status. In some cases, teachers state that they are afforded neither the time nor the funds to adopt new technologies (Levy \& Stockwell, 2008). Numerous studies note that teachers' intentions to implement ICT are often hindered by the lack of proper equipment (access to computer labs, the internet, or relevant applications) (Bingimlas, 2009; Fageeh, 2011; Hismanoglu, 2012; Mumtaz, 2000). Teachers' attitudes are therefore affected by the lack of accessibility to proper ICT resources.

While some numerous approaches and theories help researchers examine users' acceptance and adoption of information technologies, the Technology Acceptance Model (TAM) and the Unified Theory of Acceptance and Use of Technology (UTAUT) are two useful ones. TAM and UTAUT have been the most commonly used models to explain the adoption of new technology-oriented projects in several fields (Carter, 2008; Gefen \& Warkentin, 2002).

TAM, which was first founded by Davis (1989), is based on the Theory of Reasoned Action (TRA). It posits that two constructs essentially define the individual's behavioural intention for the use and acceptance of technologies: Perceived Ease of Use (PEU), and Perceived Usefulness (PU) (Davis et al., 1989). PU is "the degree to which a person believes that using a particular system would enhance his or her job performance" (Davis, 1989: p.320), whereas PEU is defined as "the degree which a person believes that using a particular system would be free of effort" (ibid.). TAM is a well-researched, simplified model that aims to explore and identify the factors that affect computer users' acceptance across various contexts. In addition, it provides predictions and explanations for whether a system will succeed (Davis et al., 1989). According to Davis et al. (1989), the TAM model suggests that the intention to use e-learning technologies increases in accordance with the usefulness and ease of use.

However, other researchers, including Bagozzi et al. (2003), suggest that, in practice, other obstacles restrict the 
user's intentions, such as limited ability, environmental or organizational capabilities, time limitations, or unconscious habits. Taylor and Todd (2001) argue that TAM fails to take into consideration other barriers that could prevent people from adopting a particular technology, adding that system design, training, support, as well as policy could play a role in accepting technology. Similarly, Bagozzi (2007) posits that the simplicity of TAM leads to overlooking certain important variables (Bagozzi, 2007).

In an effort to combine the various theories and models of technology acceptance, Venkatesh et al. (2003) developed a unification theory, by integrating components from different technology acceptance models and theories, such as TRA, TAM, the motivational model, TPB, combined TAMTPB, and TAM2 (Venkatesh, Thong, $\& \mathrm{Xu}, 2012$ ). The Unified Theory of Acceptance and Use of Technology (UTAUT) has been empirically validated with six longitudinal field studies in six different departments of six large firms from varying industries (Taiwo \& Downe, 2013).

The UTAUT model adopted four determining factors for usage and intention: performance expectancy, effort expectancy, social influence, and facilitating conditions. Gender, age, experience, and voluntariness of use are adopted to moderate the impact of the four main determinants. This will be demonstrated in further detail in the following section.

\subsection{Research Design}

After reviewing the relevant literature, this study suggests adding other parts to the UTAUT model, to account for a fuller understanding of the particulars of the overall context in Kuwait's education. This proposed model, (see Figure 1), aims to establish a more comprehensive analysis of the use and acceptance of e-learning technologies by English teachers.

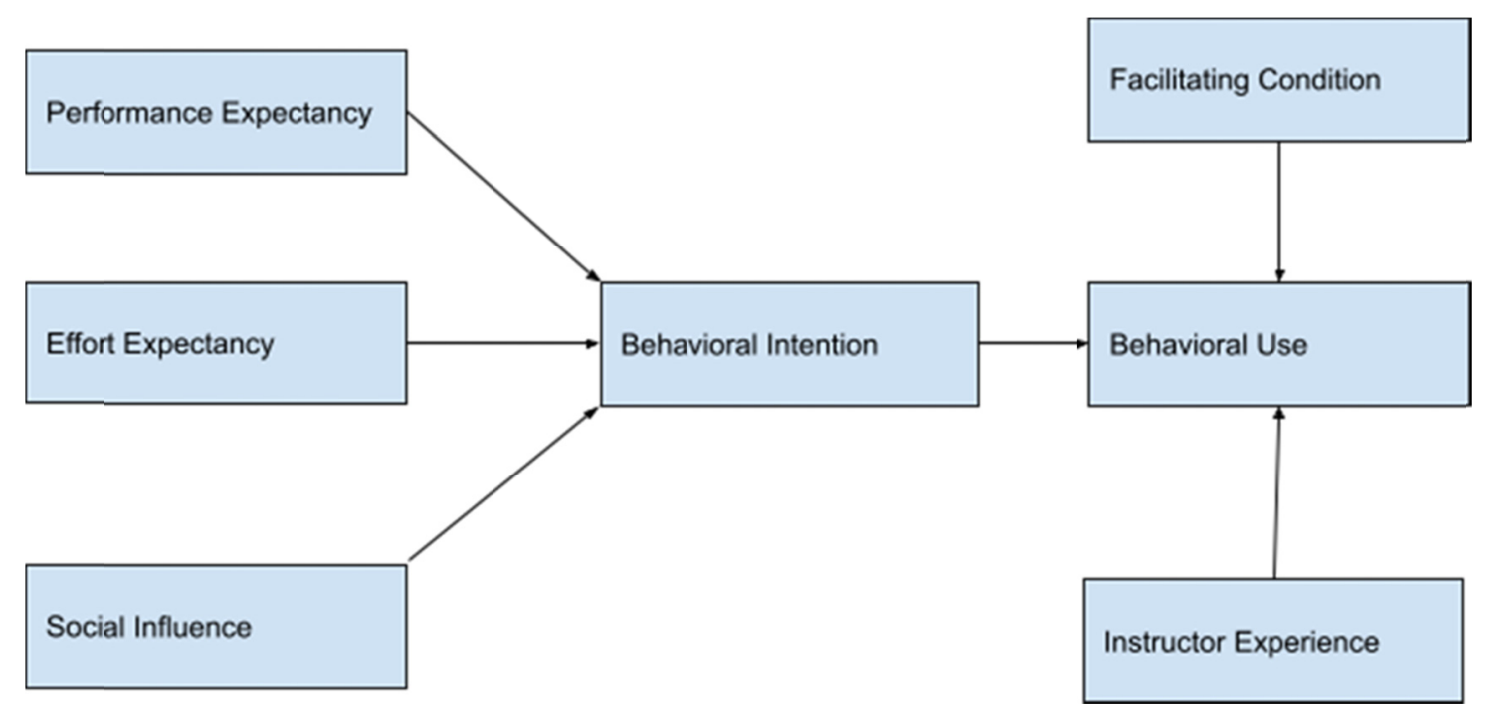

Figure 1. Proposed conceptual framework

Performance Expectancy (PE) is a variable that refers to the level an individual perceives a certain technology to help perform particular tasks (Venkatesh et al., 2012). PE, which corresponds to TAM's perceived usefulness, has been claimed as the most prominent predictor of behavioural intention. The PE construct is formed by combining factors used in other previous models to build a more comprehensive understanding. The constructs are outcome expectations and relative advantages from the Innovation Diffusion Theory, job fit from the PC Utilization Model, external motivation from the Motivational Model, and perceived usefulness from TAM (Raman et al., 2012). The benefit of using PE is in its ability to elicit individuals' perception of how useful technology can be, and how this perception is related to the user's acceptance of such technology. Alwahaishi and Snášel (2013) state that PE influences users' satisfaction and intention to long-term usage of technology. Therefore, PE can be a valid predictor of the individual's intention to adopt e-learning technologies (Bere, 2014). Therefore, it is expected that if the learning process is facilitated at a more flexible and faster rate, users will value e-learning technologies.

Effort Expectancy (EE) is another important factor in the model, as it helps users evaluate the level of effort required to use a particular technology (AlAwadhi \& Morris, 2008). According to Venkatesh et al., EE is "the degree of ease associated with the use of the system" (2003). In an educational context, EE reflects how users' beliefs towards the convenience of using e-learning technologies (Lowenthal, 2010). EE is concerned with 
technology acceptance constructs on perceptions on the convenience of use, such as the TAM's perceived ease of use (Pynoo et al., 2011), and complexity (Ghalandari, 2012). EE is considered the second independent variable in the UTAUT, which could be problematic if users find a certain e-learning technology difficult to use (Khechine et al., 2014).

Social Influence (SI) is "the degree to which an individual perceives that important others believe he or she should use the new system" (Venkatesh et al., 2003). Important others may include family members or colleagues. SI can be considered as, a subjective norm, as in C-TAM-TPB, TPB/DTPB, TAM2, part of the individual's image as in IDT, or a social factor, as in MPCU. However, they all share the position that the individual's behaviour is believed to be influenced by the attitudes of others (Bere, 2014). The value of SI stems from the fact that social influence affects the user's commitment to adopt a certain technology, as well as their usage behaviour and acceptance (Riad et al., 2013). Venkatesh et al. (2012) state that SI is moderated by other variants such as age, gender, experience, and willingness to volunteer time and effort. In educational contexts, SI is an indicator of teachers' behavioural intention to adopt e-learning, which can predict the usage of e-learning technologies (Adegbite \& Downe, 2005).

Facilitating Conditions (FC), as a UTAUT factor, refers to how the user perceives the technical readiness and infrastructure of the organization and its support (Venkatesh et al., 2003). FC is also combined from earlier models, such as compatibility, facilitating conditions, and perceived behavioural control (Bhatiasevi, 2015). In education, facilitating conditions may include school organizational policies, environment, and infrastructure, as well as e-learning content. The quality of the facilities and equipment provided by management is also one of the most important factors for the institution's environment (Blum, 2005; Dutta \& Bilbao-Osorio, 2012; Phau \& Teah, 2009).

Behavioural Intention (BI) predicts whether the individual will undertake a certain behaviour, which can be affected by several factors, such as attitudes, the perceived ease of use, and convenience. BI is considered a significant factor for using technology (AlAwadhi \& Morris, 2008; Riad et al., 2013). It is worth mentioning that perceived ease of use overrides other factors, as teachers may not use complicated systems, regardless of their attitudes towards their usefulness or convenience (Teo, 2011).

Teacher Educational Experience (TEE) is another important factor for the acceptance and planning for e-learning technologies since teachers learn from their experiences as e-learners (Donnelly \& McSweeney, 2008). The e-learning experiences of teachers are an important factor in understanding technology, as well as in improving their students' experiences. For teachers with no e-learning experiences, targeted training and support for e-learning systems are vital (Giannakos \& Vlamos, 2013). TEE can also influence the acceptance of technology, as well as the users' confidence while operating it (Alexander, 2001; Pullen, Swabey, Abadooz, Ranjit Sing, \& Kaur, 2015).

\section{Method}

The questionnaire adopted in this study is based on research on the UTAUT model by Venkatesh et al. (2003), who studied the acceptance of technology, and researchers' experiences (i.e. teachers' experiences). It was developed after reviewing relevant research, then sent to five professors for refereeing purposes, and their feedback and suggestions have been taken into consideration. The questionnaire consisted of eight sections. The first section contained an information sheet, the second section included participants' information details, and the third section consisted of performance expectancy statements. The fourth section was devoted to effort expectancy statements, followed by the fifth section statements. The sixth section was for social influence statements, with facilitating conditions statements being the seventh part, and the eighth was instructors' experiences statements 4 . The questionnaire was also piloted for reliability purposes and the result was 0.85 Cronbach's Alpha.

\subsection{Sampling Procedures}

The target population for this study is English language instructors at the language center in PAAET; participants are drawn from a total of 103 full-time English language instructors. According to PAAET, there were 103 full-time English teachers in 2019/20 teaching at English language units across PAAET's five colleges, where the Language Center provides English as a Foreign Language (EFL) courses and English for Specific Purposes (ESP) courses. Therefore, a purposive sampling protocol was applied (Cohen, Manion, \& Morrison, 2007), since the population is limited to this particular group. The questionnaire was sent to all of the English language instructors, i.e. 103. A total of 33 instructors completed the survey, representing $32.04 \%$ of the population. The participants were from all five colleges across PAAET, with varying degrees of qualifications and teaching experiences.

A survey, which was translated into Arabic and distributed online (using Google Forms), was sent to all of the instructors at the Language Center in PAAET, inviting them to take part. In reaction to the spread of COVID-19, 
PAAET has offered all of its faculty members online courses on using e-learning technologies for teaching purposes, thus encouraging them to be prepared to adopt these technologies upon their return to schools. It has also invited all students to attend online courses to learn how to use e-learning systems provided by PAAET. Similar to many educational institutions around the world, PAAET has resorted to online courses since August 2020.

\section{Results}

The researchers first used Statistical Package for the Social Sciences (SPSS) to analyze the data. In order to achieve the objectives of the study, several statistical techniques were utilized in the data analysis. The tool reliability was verified using Cronbach's alpha coefficient, as shown in Table 1 below:

Table 1. Reliability statistics

\begin{tabular}{lcc}
\hline & No. of Items & Cronbach's Alpha \\
\hline Performance expectancy & 4 & 0.90 \\
Effort expectancy & 3 & 0.83 \\
Social influence & 5 & 0.74 \\
Facilitating conditions & 3 & 0.54 \\
Behavioural intention & 3 & 0.70 \\
Actual use of e-Learning Technologies & 4 & 0.78 \\
Teacher Education Experience & 4 & 0.83 \\
Total & 26 & 0.85 \\
\hline
\end{tabular}

\subsection{The Survey}

The first part of the questionnaire includes personal information that aims to collect personal and professional data about the participants, such as age, gender, educational background, and qualifications. This helps in understanding how representative the sample was from the targeted population, in addition to getting an insight into the participants' professional experiences. The following sections will discuss each part of the survey in detail.

\subsubsection{Performance Expectancy (PE)}

A majority of participants expressed positive views regarding PE, though in varying degrees. Most of the participants $(90.9 \%)$ held positive attitudes towards e-learning for both teaching and learning, in comparison to fewer participants who were either unclear or neutral (3\%), while $6.1 \%$ disagreed. Similarly, more than $66 \%$ of the participants view e-learning technologies as a facilitating tool to achieve work more rapidly, while $54.5 \%$ thought that e-learning technologies enhanced teacher-student communication. Finally, $66.7 \%$ of the teachers found that using e-learning facilitated the teaching process. The response indicates that the majority of teachers consider e-learning technologies a valuable aid for teaching education contents, and an improvement to their performance. The results also show that English language instructors have positive attitudes towards the efficiency of e-learning technologies.

The Mean (M) of teachers' responses about how e-learning technologies help them in the teaching process (Performance Expectancy) is 3.67, while the Standard Deviation (SD) is 0.951 , which implies that e-learning technology is believed to be an efficient tool for teachers of the English Language Centre.

Table 2. Mean and standard deviation in PE

\begin{tabular}{llc}
\hline No. Statement & Mean Std. Deviation \\
\hline PE1 I find e-learning technologies useful for teaching and learning. & 4.06 & 0.933 \\
PE2 Using e-learning technologies enables me to accomplish tasks more quickly. & 3.76 & 1.119 \\
PE3 E-learning increases communication between teachers and learners. & 3.33 & 1.137 \\
PE4 Using e-learning technologies makes it easier to teach course content. & 3.55 & 1.121 \\
Total & 3.67 & 0.951 \\
\hline
\end{tabular}

\subsubsection{Effort Expectancy (EE)}

The teachers were required to evaluate the ease of using e-learning technology in their work, with most participants $(90.9 \%)$ claiming that e-learning technologies are clear and easy to use. Also, the majority of participants $(72.7 \%)$ have the required skills to adopt e-learning technologies. On the other hand, some responses 
expressed less positive, if not negative beliefs, which makes the higher positive response rate not entirely conclusive. The positive response $(72.7 \%)$ also thought that learning to operate and use new e-learning technologies was easy, which indicates that the teachers are already familiar with using e-learning technologies, and/or find them easy to learn.

The M of teachers' effort experience, i.e., how convenient it is to learn and use e-learning technology, is 3.84 , and the SD is 0.596 . This implies that the majority of the teachers in the English Language Center find it is easy to use e-learning for their educational content.

\subsubsection{Social Influence (SI)}

The survey findings indicate that SI regarding e-learning technologies has an impact on their users. Firstly, more than half of the participants (54.5\%) believed that their dean and supervisor think that they should use e-learning technologies. Only one participant did not think this was the case, while the rest $(42.2 \%)$ were neutral. Although $51.5 \%$ believed that colleagues assist one another when facing difficulty in using e-learning technologies, a sizable minority (48.4\%) thought otherwise. However, the majority of instructors were neutral (54.5\%) or did not agree $(18.2 \%)$ that students prefer adopting e-learning technologies in their courses.

Similarly, despite the fact more than half the participants $(51.5 \%)$ believed their colleagues acknowledge the importance of e-learning, there were noticeable responses with either neutral $(36.4 \%)$ or negative $(12.1 \%)$ position towards staff perception of e-learning technologies. Finally, teachers' responses about their superiors' beliefs, colleagues' collaboration, and students' expectations show that SI positively impacts teachers' perceptions towards using e-learning technologies.

Table 3. Social influence

\begin{tabular}{lcccccccccc}
\hline & \multicolumn{1}{c}{ Strongly Disagree } & Disagree & Neutral & \multicolumn{2}{c}{ Agree } & \multicolumn{2}{c}{ Strongly Agree } \\
\cline { 2 - 10 } Frequency/Percentage & $\mathrm{F}$ & $\%$ & $\mathrm{~F}$ & $\%$ & $\mathrm{~F}$ & $\%$ & $\mathrm{~F}$ & $\%$ & $\mathrm{~F}$ & $\%$ \\
\hline The dean and supervisor think that I should use e-learning technologies. & 1 & 3.0 & 0 & 0 & 14 & 42.4 & 11 & 33.3 & 7 & 21.2 \\
My colleagues have helped me to use e-learning technologies. & 1 & 3.0 & 7 & 21.2 & 8 & 24.2 & 14 & 42.4 & 3 & 9.1 \\
My students think that I should use e-Learning technologies. & 1 & 3.0 & 5 & 15.2 & 18 & 54.5 & 8 & 24.2 & 1 & 3.0 \\
Most staff in my college thinks e-learning is important. & 0 & 0 & 4 & 12.1 & 12 & 36.4 & 17 & 51.5 & 0 & 0 \\
\hline
\end{tabular}

The M of sample responses on (SI) is 3.28, with an SD of 0.589. This highlights the mainly positive perceptions from instructors towards other people's ideas about their use of e-learning technologies.

\subsubsection{Facilitating Conditions (FC)}

The survey established that the majority of participants $(63.6 \%)$ believe that classes in their college are inadequately equipped with computers. However, the majority (57.5\%) believed they had the resources necessary to use e-learning. Also, more than half of the participants (51.6\%) stated that technical assistance was available by personnel or department dedicated to e-learning technology issues.

Overall, it seems that there are no satisfactory e-learning technologies facilitating conditions, which limits English language instructors' potential of maximizing the potential of e-learning technologies.

The $\mathrm{M}$ of sample responses about instructors' perception of the current technological facilities for e-learning technologies (FC) is 2.95 , with an SD of 0.854 . This shows prevailing negative attitudes from the teachers towards the provided technological facilities at work that could help them adopt e-learning.

\subsubsection{Behavioural Intention (BI)}

Statements on BI reported positive attitudes from most of the participants towards using e-learning technologies in the future. Most of the participants responded positively to $(81.9 \%)$ attending training courses for e-learning technologies, with a few $(21.1 \%)$ uncertain, and even fewer (6.1\%) not showing interest in attending e-learning technologies training. This shows an overall positive attitude and behavioural intention towards using and learning how to use e-learning technologies by English language instructors, which is an important indicator of their belief that e-learning technologies would improve the learning and teaching experience.

The $\mathrm{M}$ of the responses on teachers' $\mathrm{BI}$ about using e-learning technologies is 4.17, with an SD of 0.693, indicating very high behavioural intentions from the teachers to use e-learning technologies. 


\subsubsection{Behavioural Use (BU)}

The survey showed that all participants use computers as part of their preparation, either daily (69.7\%), or weekly (30.3\%). However, when it comes to using computers as part of the teaching process, most use them daily or weekly (75.8\%), while $15.2 \%$ use them scarcely, and $12.1 \%$ never use computers for teaching. The most used presentational tools used were data Show (51.5\%), and PowerPoint (45.4\%). However, a significant minority said they never use Data Show (33.3\%) or PowerPoint (39.4\%) as part of their teaching. It can be argued that using these e-learning tools provides teachers with more efficient and diverse tools for teaching and presenting information to students.

The $\mathrm{M}$ of instructors' use of e-learning technologies is 3.50, with an SD of 1.053. This confirms a high usage of e-learning technologies by teachers.

\subsubsection{Educational Experience (EE)}

The survey aimed to understand the English language instructors' experience with e-learning technologies when they were students. However, more than half the participants (54.5\%) stated that they had never used e-learning technologies in high school, while the rest either used it rarely, weekly, or daily. On the other hand, most of the participants reported regular e-learning technology use at the college level, either by them or their lecturers, with a notable minority indicating that have never, or scarcely, used e-learning technologies at the tertiary level. Similar views were also expressed regarding pre-service teacher training, with $45.5 \%$ of participants using e-learning technology regularly, and $36.4 \%$ rarely using them, while $18.2 \%$ stated that they never used them.

The $\mathrm{M}$ of instructors' educational experience in using e-learning technologies is 3.99, with an SD of 0.937 , meaning there is an overall high level of experience among teachers in using e-learning technologies as students on varying levels.

\subsection{Correlations}

Correlations are used to examine the acceptance and use of e-learning technology in relation to other variants in the study. Also, Significance Testing is used to test the patterns and differences, and whether they occur by chance (Berman, Brown, \& Saunders, 2008).

Table 4. Correlations

\begin{tabular}{|c|c|c|c|c|c|c|c|}
\hline & $\begin{array}{l}\text { Performance } \\
\text { Expectancy }\end{array}$ & $\begin{array}{c}\text { Effort } \\
\text { Expectancy }\end{array}$ & $\begin{array}{c}\text { Social } \\
\text { Influence }\end{array}$ & $\begin{array}{l}\text { Facilitating } \\
\text { Conditions }\end{array}$ & $\begin{array}{l}\text { Behavioural } \\
\text { Intention }\end{array}$ & $\begin{array}{c}\text { Behavioural } \\
\text { Use }\end{array}$ & $\begin{array}{c}\text { Teacher Education } \\
\text { Experience }\end{array}$ \\
\hline $\begin{array}{l}\text { Performance } \\
\text { Expectancy }\end{array}$ & 1 & $.649 * *$ & 0.100 & $.354^{*}$ & $.661^{* *}$ & 0.162 & 0.343 \\
\hline Effort Expectancy & $.649 * *$ & 1 & -0.105 & $.570 * *$ & $.540 * *$ & 0.100 & $.511 * *$ \\
\hline Social Influence & 0.100 & -0.105 & 1 & 0.124 & -0.060 & 0.030 & -0.041 \\
\hline $\begin{array}{l}\text { Facilitating } \\
\text { Conditions }\end{array}$ & $.354 *$ & $.570 * *$ & 0.124 & 1 & 0.267 & -0.055 & 0.133 \\
\hline $\begin{array}{c}\text { Behavioural } \\
\text { Intention }\end{array}$ & $.661 * *$ & $.540 * *$ & -0.060 & 0.267 & 1 & 0.203 & 0.335 \\
\hline Behavioural Use & 0.162 & 0.100 & 0.030 & -0.055 & 0.203 & 1 & $.433^{*}$ \\
\hline $\begin{array}{c}\text { Teacher Education } \\
\text { Experience }\end{array}$ & 0.343 & $.511 * *$ & -0.041 & 0.133 & 0.335 & $.433^{*}$ & 1 \\
\hline
\end{tabular}

Effort Expectancy is significantly positively correlated with Performance Expectancy ( $r=.649)$, Facilitating Conditions $(\mathrm{r}=.570)$, Behavioural Intention $(\mathrm{r}=.540)$, and Teacher Education Experience $(\mathrm{r}=.511)$. The level of these four coefficients shows a high correlation with Effort Expectancy.

Similarly, Performance Expectancy is significantly positively correlated with Effort Expectancy ( $\mathrm{r}=.649)$, Facilitating Conditions ( $\mathrm{r}=.354)$, and Behavioural Intention ( $\mathrm{r}=.661)$. The magnitude of these three coefficients shows a moderate correlation with Performance Expectancy.

Likewise, Facilitating Conditions reports positive correlations with Performance Expectancy $(r=.354)$ and Effort Expectancy $(r=.570)$. The magnitude of these two coefficients shows a moderate correlation with Performance 


\section{Expectancy.}

In the same vein, Teacher Education Experience is significantly positively correlated with Effort Expectancy $(\mathrm{r}=.511)$ and Behavioural Use $(\mathrm{r}=.433)$. The magnitude of these two coefficients shows a moderate correlation with Teacher Education Experience. Behavioural Use is significantly positively correlated only with Teacher Education Experience $(\mathrm{r}=.433)$. The magnitude of this coefficient shows a moderate correlation with Teacher Education Experience.

To sum up, the questionnaire revealed notable features regarding the acceptance and use of e-learning technologies among the PAAET English language instructors. Overall, survey respondents showed positive attitudes towards using technology for teaching purposes, as they find it easy to use and agree it improves their teaching experience. However, they expressed varying responses about the attitudes of people in the workplace towards their use of e-learning technologies, although more than half the participants reported positive responses. Even though facilitating conditions in PAAET are below the participants' expectations, most of them expressed their desire to adopt e-learning technologies for their classes, if it isn't already part of their teaching experience. When investigating correlations among the variables that could influence adopting and using e-learning technologies, significant correlations were found between Behavioural Intention and other factors to use these technologies.

\section{Discussion}

In general, the majority of instructors from the Language Center at PAAET showed positive attitudes towards using and accepting technologies.

\subsection{Performance Expectancy (PE)}

Prior research has established a relationship between PE and Behavioural Intention to use e-learning technologies (Pullen et al., 2015; Lowenthal, 2010; San Martin \& Herrero, 2012; Venkatesh et al., 2003). In this current study, four questions were devised to test key aspects of $\mathrm{PE}$, notably how teachers perceived the usefulness of e-learning technologies for teaching and learning, to accomplish tasks faster, to communicate with students, and to facilitate teaching course content. The survey findings revealed that teachers were almost unanimous in their agreement that e-learning technologies were useful in their replies to all four questions. The overall $\mathrm{M}$ of the PE scale was (3.67), while the SD was (0.951), which underscores a high level of influence from PE on the use of e-learning technologies.

It can be concluded that PE can help explain variances in English language instructors' Behavioural Intention to engage with e-learning. Although teachers find it difficult to adopt e-learning technologies in their teaching practices, they still expect e-learning tools to improve the educational experience for teachers and students alike. This indicates that English language instructors would engage with e-learning when they deem it beneficial for their educational experience.

\subsection{Effort Expectancy (EE)}

In this study, EE is defined as the ease of use of e-learning technologies at PAAET colleges. The majority of English language instructors had positive attitudes towards the ease of use of e-learning technologies. The results show that EE positively influences teachers' intention to use e-learning technologies. These findings are in linee with prior studies (Venkatesh et al., 2003, Venkatesh \& Zhang, 2010; Wang \& Shih, 2009).

The survey aimed to find out how the instructors perceive the ease and convenience of using e-learning technologies. In their responses, English language instructors have overwhelmingly shown that they find learning new technologies is an easy task, with the majority of them describing these technologies as clear and easy to use. The relevance of EE in this study is also reflected in earlier research (Im, Kim, \& Han, 2008; Schaik, 2009), which finds that an increase in EE leads to an improvement in Behavioural Intention to accept and use e-learning technologies.

\subsection{Social Influence (SI)}

The SI variable is defined as the degree to which an individual perceives others' opinions as being important in respect to whether they should use new technologies such as e-learning technologies (Venkatesh, Davis, \& Morris, 2007).

The survey investigated how teachers believe whether their colleagues, superiors, and students expected them to use e-learning and if they provided assistance in that respect. It also aimed to understand how the respondents view the perception of other people in their organization towards e-learning technologies. In contrast to previous studies, (Chan et al., 2010; Cheng, Yang, King, \& Lyu, 2011; Loo, Yeow, \& Chong, 2009), SI did not appear to have a substantial influence on English language instructors' intention to use e-learning technologies. According to 
findings in this study, SI does not seem to be an important factor for instructors' intentions to adopt e-learning technologies. This might be because there was not a clear policy or guidebook to help the instructors use e-learning technologies at the time of conducting this research. Indeed, PAAET only announced its intention to universally adopt e-learning technologies after the spread of the coronavirus impacted schools. (KUNA, 2020).

\subsection{Facilitating Conditions (FC)}

The FC construct in this study refers to the available technological and organizational resources to support the use of e-learning technologies (Venkatesh et al., 2003). FC was measured as the extent to which the necessary resources and technical support were provided, as well as the readiness of the classrooms and infrastructural foundations for e-learning technologies within the institution. Numerous studies have established that FC has a clear influence on the actual use of technology (Al Awadhi \& Morris, 2008; Tibenderana, Ogao, Ikoja-Odongo, \& Wokadala, 2010).

The results indicate that the English language instructors' attitudes towards the facilities that currently support their use of e-learning technologies are generally negative. However, the majority of instructors have expressed that they have the required resources to use e-learning technologies in college. This might be because they buy their resources.

\subsection{Behavioural Intention (BI)}

Williams, Rana, and Dwivedi (2015) argued that research has shown that BI was the only consistent factor in the UTAUT that could significantly predict the acceptance and use of e-learning technologies. The current study is consistent with the literature, as the English language instructors' BI to adopt e-learning methods, learn new technologies, or takes the required training, is positive. This factor was shown to be significant in explaining the variant degrees in English language instructors' use of e-learning technologies. A notable number of instructors reported their intention to attend training sessions, which means that they want to enhance their technological abilities for e-learning purposes.

\subsection{Behavioural Use (BU)}

It could be argued that, with the increase in online learning due to the COVID-19 restrictions, teachers would essentially increase their dependency on technology for teaching purposes.

\subsection{Instructor Experience (IE)}

A number of authors have suggested that IE influences teachers' attitudes about e-learning and that the degree of experience (e.g. high or low) can be related to the degree of certainty or hesitation in accepting and using e-learning technologies (Donnelly \& McSweeney, 2008; Jimoyiannis \& Komis, 2008; Wong \& Shih, 2012).

The responses to IE questions in the survey show that a minority of the respondents reported using or experiencing the use of e-learning technologies as students. This can be related to the fact that education in Kuwait has been largely dependent on traditional learning methods at all levels since its inception. It can also be a result of the lack of proper technical infrastructure and technical training at educational institutes.

In conclusion, it can be argued that English academic staff accepts and uses technology to a large extent during the COVID-19 pandemic, although they asserted that technology facilities at their colleges are inadequate. At the same time, they have access to technologies that allow them to present their lessons; this might be due to the subjects they teach, with a large number of free online content for English language lessons. The study found a high level of acceptance and use of technology for educational purposes.

\section{Acknowledgments}

The authors would like to thank the English language instructors who participated in this study, the College of Basic Education (CBE) for cooperating in the carrying out of this piece of research during the spring semester of the academic year 2019/20, and fellow professors who helped pilot the survey, and provided valuable feedback.

\section{References}

Adegbite, A., \& Downe, A. (2005). The theory of user acceptance and use of technology (UTAUT): A meta-analytic review of empirical findings. Journal of Theoretical and Applied Information Technology, $49(1), 48-58$.

Afshari, M., Ghavifekr, S., Siraj, S., \& Jing, D. (2013). Students' attitudes towards computer-assisted language $\begin{array}{llll}\text { learning. Procedia-Social and Behavioral } & \text { Sciences, } & \text { 103(2), }\end{array}$ https://doi.org/10.1016/j.sbspro.2013.10.407

AlAwadhi, S. \& Morris, A. (2008, January). The Use of the UTAUT Model in the Adoption of E-government 
Services in Kuwait. In Proceedings of the 41st annual Hawaii international conference on system sciences (HICSS 2008) (pp. 219-219). https://doi.org/10.1109/HICSS.2008.452

Al-Daihani, S. M. (2016). Students' adoption of Twitter as an information source: An exploratory study using the Technology Acceptance Model. Malaysian Journal of Library \& Information Science, 21(3), 57-69. https://doi.org/10.22452/mjlis.vol21 no3.4

Alexander, S. (2001). E-learning Developments and Experiences. Education + Training, 43(4/5), 240-248. https://doi.org/10.1108/00400910110399247

Alia, A. (2017). An investigation of the application of the Technology Acceptance Model (TAM) to evaluate instructors' perspectives on E-Learning at Kuwait University (Unpublished doctoral dissertation). Dublin City University, Dublin, Ireland.

Alkandari, B. (2015). An investigation of the factors affecting students' acceptance and intention to use e-learning systems at Kuwait University: Developing a technology acceptance model in e-learning environments (Doctoral dissertation, Cardiff Metropolitan University).

Alwahaishi, S., \& Snášel, V. (2013). Consumers' acceptance and use of information and communications technology: UTAUT and flow-based theoretical model. Journal of Technology Management and Innovation, 8(2), 61-73. https://doi.org/10.4067/S0718-27242013000200005

Bagozzi, R. P. (2007). The legacy of the technology acceptance model and a proposal for a paradigm shift. Journal of the Association for Information Systems, 8(4), 3. https://doi.org/10.17705/1jais.00122

Bagozzi, R. P., Bergami, M., \& Leone, L. (2003). Hierarchical representation of motives in goal setting. Journal of Applied Psychology, 88(5), 915. https://doi.org/10.1037/0021-9010.88.5.915

Bere, A. (2014). Exploring Determinants for Mobile Learning User Acceptance and Use: An Application of UTAUT. 11th International Conference on Information Technology: New Generations. https://doi.org/10.1109/ITNG.2014.114

Bhatiasevi, V. (2015). An extended UTAUT model to explain the adoption of mobile banking. Information Development, 1-16.

Bingimlas, K. A. (2010). Evaluating the quality of science teachers' practices in ICT-supported learning and teaching environments in Saudi primary schools (Unpublished PhD thesis). RMIT University, Melbourne, Australia.

Blackwell, C. K., Lauricella, A. R., \& Wartella, E. (2014). Factors influencing digital technology use in early childhood education. Computers \& Education, 77, 82-90. https://doi.org/10.1016/j.compedu.2014.04.013

Blum, R. (2005). Best Practices: Building blocks for enhancing school environment. Retrieved from http://www.jhsph.edu/research/centers-and-institutes/military-child-initiative/resources/Best_Practices_mon ograph.pdf

Camilleri, M. A., \& Camilleri, A. (2017, April). The technology acceptance of mobile applications in education. In 13th International Conference on Mobile Learning (Budapest, April 10th). Proceedings, International Association for Development of the Information Society.

Chan, F. K., Thong, J. Y., Venkatesh, V., Brown, S. A., Hu, P. J., \& Tam, K. Y. (2010). Modeling citizen satisfaction with mandatory adoption of an e-government technology. Journal of the Association for Information Systems, 11(10), 519-549. https://doi.org/10.17705/1jais.00239

Cheng, C., Yang, H., King, I., \& Lyu, M. R. (2012, July). Fused matrix factorization with geographical and social influence in location-based social networks. Aaai, 12, 17-23.

Cohen, L., Manion, L., \& Morrison, K. (2007). Research Methods in Education (6th ed.). London: Routledge Falmer. https://doi.org/10.4324/9780203029053

Davis, F. D. (1989). Perceived usefulness, perceived ease of use and user acceptance of information technology. MIS Quarterly, 13, 319-340. https://doi.org/10.2307/249008

Donnelly, R., \& McSweeney, F. (2008). Applied e-learning and e-teaching in higher education (1st ed.). Information Science Reference (an imprint of IGI Global): United States of America. https://doi.org/10.4018/978-1-59904-814-7

Dutta, S., Bilbao-Osorio, B., \& Geiger, T. (2012). The networked readiness index 2012: Benchmarking ICT progress and impacts for the next decade. The global information technology report, 3-34. 
Edwards, S., Nuttall, J., Mantilla, A., Wood, E., \& Grieshaber, S. (2015). Digital play: What do early childhood teachers see? In Critical perspectives on technology and education (pp. 69-84). Palgrave Macmillan, New York. https://doi.org/10.1057/9781137385451_5

Elias, S. M., Smith, W. L., \& Barney, C. E. (2012). Age as a moderator of attitude towards technology in the workplace: work motivation and overall job satisfaction. Behaviour \& Information Technology, 31(5), 453-467. https://doi.org/10.1080/0144929X.2010.513419

Fageeh, A. I. (2011). EFL learners' use of blogging for developing writing skills and enhancing attitudes towards English learning: An exploratory study. Journal of Language and Literature, 2(1), 31-48.

Gefen, D., Warkentin, M., Pavlou, P., \& Rose, G. (2002). E Government adoption. AMCIS 2002 Proceedings, 83.

Ghalandari, K. (2012). The effect of performance expectancy, effort expectancy, social influence and facilitating conditions on acceptance of e-banking services in Iran: The moderating role of age and gender. Middle-East Journal of Scientific Research, 12(6), 801-807.

Giannakos, M. N., \& Vlamos, P. (2013) Educational webcasts' acceptance: Empirical examination and the role of experience. British Journal of Educational Technology, 44(1), 125-143. https://doi.org/10.1111/j.1467-8535.2011.01279.x

Hismanoglu, M. (2012). Prospective EFL teachers' perceptions of ICT integration: A study of distance higher education in Turkey. Journal of Educational Technology \& Society, 15(1), 185-196.

Im, I., Kim, Y., \& Han, H.-J. (2008). The effects of perceived risk and technology type on users' acceptance of technology. Information \& Management, 45(1), 1-9. https://doi.org/10.1016/j.im.2007.03.005

Jimoyiannis, A., \& Komis, V. (2007). Examining teachers' beliefs about ICT in education: Implications of a teacher preparation programme. Teacher Development, 11(2), 149-173. https://doi.org/10.1080/13664530701414779

Kalogiannakis, M. (2010). Training with ICT for ICT from the trainee's perspective. A local ICT teacher training $\begin{array}{lllll}\text { experience. } \quad \text { Education and Information } & \text { Technologies, } & 15(1), & 3-17 .\end{array}$ https://doi.org/10.1007/s10639-008-9079-3

Kukulska-Hulme, A., \& Viberg, O. (2018). Mobile collaborative language learning: State of the art. British Journal of Educational Technology, 49(2), 207-218. https://doi.org/10.1111/bjet.12580

Levy, M., \& Stockwell, G. (2006). CALL Dimensions: Options and Issues in Computer Assisted Language Learning. Mahwah, NJ: Lawrence Erlbaum.

Liu, Y. (2010). Social media tools as a learning resource. Journal of Educational Technology Development and Exchange, 3(1), 101-114. https://doi.org/10.18785/jetde.0301.08

Loo, W. H., Yeow, P. H., \& Chong, S. C. (2009). User acceptance of Malaysian government multipurpose smartcard applications. Government Information Quarterly, 26(2), 358-367. https://doi.org/10.1016/j.giq.2008.07.004

Lowenthal, J. (2010). Using Mobile Learning: Determinates Impacting Behavioral Intention. American Journal of Distance Education, 24(4), 195-206. https://doi.org/10.1080/08923647.2010.519947

Mumtaz, S. (2000). Factors affecting teachers' use of information and communications technology: A review of the literature. Journal of Information Technology for Teacher Education, 9(3), 319-342. https://doi.org/10.1080/14759390000200096

Phau, I., \& Teah, M. (2009). Devil wears (counterfeit) Prada: a study of antecedents and outcomes of attitudes towards counterfeits of luxury brands. Journal of Consumer Marketing. https://doi.org/10.1108/07363760910927019

Pinto, J. K., \& Mantel, S. J. (1990). The causes of project failure. IEEE Transactions on Engineering Management, 37(4), 269-276. https://doi.org/10.1109/17.62322

Pullen, D., Swabey, J. F., Abadooz, K., Ranjit Sing, M., \& Kaur, T. (2015) Pre-service teachers' acceptance and use of mobile learning in Malaysia. Australian Educational Computing, 30(1).

Pynoo, B., Devolder, P., Tondeur, J., Van Braak, J., Duyck, W., \& Duyck, P. (2011). Predicting secondary school teachers' acceptance and use of a digital learning environment: A cross-sectional study. Computers in Human Behavior, 27(1), 568-575. https://doi.org/10.1016/j.chb.2010.10.005

Raman, A., Don, Y., Khalid, R., \& Rizuan, M. (2014). Usage of Learning Management System (Moodle) among 
Postgraduate Students: UTAUT Model Arumugam. Asian Social Science, 10(14), 186-192. https://doi.org/10.5539/ass.v10n14p186

Reuters. (2020, March 19). Kuwait extends schools, universities suspension to Aug. 4 - state news agency. Retrieved from https://www.reuters.com/

Rouibah, K., \& Abbas, H. (2006). A modified technology acceptance model for camera mobile phone adoption: development and validation. ACIS 2006 Proceedings, 13.

San Martin, H., \& Herrero, A. (2012). Influence of the user's psychological factors on the online purchase intention in rural tourism: Integrating innovativeness to the UTAUT framework. Tourism Management, 33(2), 341-350. https://doi.org/10.1016/j.tourman.2011.04.003

Schaik, P. (2009). Unified theory of acceptance and use for websites used by students in higher education. Journal of Educational Computing Research, 40(2), 229-257. https://doi.org/10.2190/EC.40.2.e

Shroff, R. H., Deneen, C. C., \& Ng, E. M. (2011). Analysis of the technology acceptance model in examining students' behavioural intention to use an e-portfolio system. Australasian Journal of Educational Technology, 27(4). https://doi.org/10.14742/ajet.940

Sime, D., \& Priestley, M. (2005). Student teachers' first reflections on information and communications technology and classroom learning: Implications for initial teacher education. Journal of Computer Assisted Learning, 21(2), 130-142. https://doi.org/10.1111/j.1365-2729.2005.00120.x

Succi, M. J., \& Walter, Z. D. (1999, January). Theory of user acceptance of information technologies: an examination of health care professionals. In Proceedings of the 32nd Annual.

Taiwo, A. A., \& Downe, A. G. (2013). The theory of user acceptance and use of technology (UTAUT): A meta-analytic review of empirical findings. Journal of Theoretical \& Applied Information Technology, $49(1)$.

Taylor, T. B. (2001). Threats to the health care safety net. Academic Emergency Medicine, 8(11), 1080-1087. https://doi.org/10.1111/j.1553-2712.2001.tb01119.x

Teo, T. (2011). Factors influencing teachers' intention to use technology: Model development and test. Computers \& Education, 57, 2432-2440. https://doi.org/10.1016/j.compedu.2011.06.008

Tibenderana, P., Ogao, P., Ikoja-Odongo, J., \& Wokadala, J. (2010). Measuring levels of end-users' acceptance and use of hybrid library services. International Journal of Education and Development Using ICT, 6(2), 33-54.

UNESCO. (2020, March 24). 1.37 billion students now home as COVID-19 school closures expand, ministers scale up multimedia approaches to ensure learning continuity. Retrieved from https://en.unesco.org/news/

Venkatesh, V., \& Zhang, X. (2010). Unified theory of acceptance and use of technology: U.S. vs. China. Journal of Global Information Technology Management, 13(1), 5-27. https://doi.org/10.1080/1097198X.2010.10856507

Venkatesh, V., Davis, F., \& Morris, M. G. (2007). Dead or alive? The development, trajectory and future of technology adoption research. Journal of the Association for Information Systems, 8(4), 1. https://doi.org/10.17705/1jais.00120

Venkatesh, V., Morris, M., Davis, G., \& Davis, F. (2003). User acceptance of information technology: toward a unified view. MIS Quarterly, 27(3), 425-478. https://doi.org/10.2307/30036540

Venkatesh, V., Thong, J., \& Xu, X. (2012). Consumer acceptance and use of information technology: Extending the unified theory of acceptance and use of technology. MIS Quarterly, 36(1), 157-178. https://doi.org/10.2307/41410412

Wang, Y. S., \& Shih, Y. W. (2009). Why do people use information kiosks? A validation of the unified theory of acceptance and use of technology. Government Information Quarterly, 26(1), 158-165. https://doi.org/10.1016/j.giq.2008.07.001

Williams, M. D., Rana, N. P., \& Dwivedi, Y. K. (2015). The unified theory of acceptance and use of technology (UTAUT): A literature review. Journal of Enterprise Information Management, 28(3), 443-488. https://doi.org/10.1108/JEIM-09-2014-0088 


\section{Copyrights}

Copyright for this article is retained by the author(s), with first publication rights granted to the journal.

This is an open-access article distributed under the terms and conditions of the Creative Commons Attribution license (http://creativecommons.org/licenses/by/4.0/). 